\title{
KARAKTERISASI SPESIFIK DAN NON SPESIFIK EKSTRAK ETANOL DAUN PUTAT (Planchonia valida)
}

\author{
Risa Supriningrum ${ }^{1)}$, Nurul Fatimah ${ }^{2)}$ dan Yenni Eka Purwanti ${ }^{3)}$ \\ ${ }^{1,2,3}$ Prodi D-3 Farmasi, Sekolah Tinggi Ilmu Kesehatan Samarinda \\ Email: risa.stikesam@gmail.com
}

\begin{abstract}
Putat plant (Planchonia valida) is a medicinal plant that grows in Mahulu, East Kalimantan. Empirically putat leaves are used to treat skin diseases and reduce black spots on the face. Characterization is the initial stage to determine the quality of an extract. Non-experimental research was conducted to determine the specific and non-specific characteristics of putat plants. Samples in the form of putat shoots were obtained from Mahulu Long Melaham Village, Long Bagun District, Mahakam Ulu Regency, East Kalimantan. The stages of the research include plant determination, sample collection, processing of simplicia, extraction using maceration methods, specific and non specific extracts characterization. Specific characteristics of putat leaf extract include organoleptic test in the form of thick extract, blackish brown color, characteristic odor, bitter taste, average water soluble extract content of $62.50 \%$ and ethanol soluble extract $48.75 \%$. Secondary metabolites of putat leaf ethanol extract are alkaloids, flavonoids, tannins, saponins, and steroids. The non-specific characteristics of putat leaf extract include average water content of $23.00 \%$, ash content of $6.47 \%$ and acid insoluble ash content of $0.06 \%$.
\end{abstract}

Keywords: Planchonia valida, Characterization, Ethanol extract

\section{PENDAHULUAN}

Tumbuhan obat di Indonesia mempunyai peran yang sangat penting terutama bagi masyarakat di daerah pedesaan yang fasilitas kesehatannya masih sangat terbatas. Masyarakat sekitar kawasan hutan memanfaatkan tumbuhan obat sebagai bahan baku obat berdasarkan pengetahuan tentang pemanfaatan tumbuhan obat yang diwariskan secara turun-temurun (Hidayat dan Hardiyansyah, 2012)

Salah satu tumbuhan berkhasiat obat ialah tumbuhan putat. Tumbuhan putat memiliki nama ilmiah Planchonia valida famili Lecythidaceae. Tumbuhan ini hidup di hutan Malaysia, Sumatera, Kalimantan, Jawa, Sulawesi, Bali, Lombok, Sumba, Sumbawa, Pulau Komodo dan Timor. Spesies ini banyak ditemukan di daerah yang lembab, di sepanjang tepi sungai atau dataran dan daratan alluvial dan pegunungan pada ketinggian 0 hingga 1000 meter, dengan curah hujan tahunan rata-rata mulai dari $1100 \mathrm{~mm}$ hingga $3800 \mathrm{~mm}$ (Hardiyanto, 2008).
Secara empiris masyarakat Mahakam Ulu Kalimantan Timur menggunakan tumbuhan putat sebagai obat tradisional. Bagian tumbuhan yang digunakan ialah daun. Daun putat dapat digunakan untuk mengobati penyakit kulit seperti gatal-gatal dengan cara daun ditumbuk kemudian ditempelkan di daerah yang gatal. Daun putat digunakan juga sebagai campuran air mandi pasca melahirkan. Selain menjadi obat, umumnya masyarakat Mahakam Ulu menggunakan daun putat sebagai campuran bedak dingin dan digunakan untuk melindungi kulit dari paparan sinar matahari ketika sedang di ladang dan dapat menghilangkan flek-flek hitam di wajah.

Penelitian tentang pemanfaatan daun putat belum banyak dilakukan, sehingga perlu dilakukan agar diperoleh banyak informasi secara ilmiah. Mengingat daun putat dapat digunakan sebagai obat, maka perlu dilakukan karakterisasi. Karakterisasi sebagai tahap awal untuk mengetahui mutu ekstrak, agar ekstrak yang diperoleh aman digunakan sebagai 
bahan obat. Karakterisasi meliputi karakterisasi spesifik dan non spesifik.

\section{METODE PENELITIAN}

Sampel yang digunakan pada penelitian ini adalah pucuk daun putat yang diperoleh dari hutan di Desa Mahulu Long Melaham, Kecamatan Long Bgun, Kabupaten mahakan Ulu, Kalimantan Timur pada bulan Desember 2018. Pucuk daun putat diambil dari nodus ke 1 sampai nodus ke 3 tumbuhan Planchonia valida.

\section{Alat}

Alat-alat gelas, ayakan mesh 60, desikator, cawan porselen, krus platina, lampu spiritus, neraca analitik (Ohaus), oven (Memmert)

\section{Bahan}

Air suling, amil alkohol, asam asetat anhidrat, asam klorida $2 \mathrm{~N}$, asam klorida pekat, asam sulfat pekat, besi (III) klorida 1\%, daun putat, etanol $70 \%$, pereaksi bouchardat, pereaksi dragendorf, pereaksi meyer, dan serbuk magnesium.

\section{Prosedur Kerja}

1. Pengolahan simplisia

Pucuk daun putat yang telah dipanen dicuci bersih, dirajang dan dikeringkan hingga diperoleh simplisia kering. Simplisia dihaluskan dan diayak dengan ayakan mesh 60 .

2. Pembuatan Ekstrak

Sebanyak 200 gram simplisia serbuk dimaserasi dengan pelarut etanol $70 \%$ sebanyak $1000 \mathrm{ml}$, direndam selama 6 jam pertama sambil sesekali diaduk, kemudian didiamkan selama 18 jam. Maserat dipisahkan dengan cara filtrasi, ampas dimaserasi kembali dengan $1000 \mathrm{ml}$ etanol $70 \%$. Semua maserat, diuapkan hingga diperoleh ekstrak kental (Depkes RI, 2008).

\section{Karakterisasi}

a. Karakterisasi spesifik dalam penelitian ini meliputi :

\section{1) Uji Organoleptik}

Uji organoleptik terhadap ekstrak dilakukan dengan cara yaitu : mencium bau dari ekstrak, mengetahui rasa ekstrak, melihat warna ekstrak dan melihat bentuk ekstrak daun putat (Depkes RI, 2000).

\section{2) Penetapan Kadar Sari Larut Air}

Sebanyak 5 gram ekstrak, dimaserasi selama 24 jam dengan $100 \mathrm{ml}$ air - kloroform $(2,5 \mathrm{ml}$ kloroform dalam air suling $1000 \mathrm{ml}$ ), dalam labu bersumbat, sambil dikocok tiap jam, selama 6 jam pertama dan dibiarkan selama 18 jam. Disaring, diuapkan $20 \mathrm{~mL}$ filtrat hingga kering dalam cawan dangkal berdasar rata yang telah ditara, residu dipanaskan pada suhu $105^{\circ} \mathrm{C}$ hingga bobot tetap. Kadar dihitung dalam persen senyawa yang larut dalam air terhadap ekstrak awal (Depkes RI, 2000).

Kadar sari larut air $=\frac{\text { Berat Sari Air }(g)}{\text { Berat Ekstrak }(g)} \times\left(\frac{100}{20}\right) \times 100 \%$

\section{3) Penetapan Kadar Sari Larut Etanol}

Sebanyak 5 gram ekstrak, dimaserasi selama 24 jam dengan $100 \mathrm{~mL}$ etanol (95\%), menggunakan labu bersumbat sambil dikocok tiap jam, selama 6 jam pertama dan dibiarkan selama 18 jam. Disaring cepat dengan menghindarkan penguapan etanol, kemudian diuapkan $20 \mathrm{~mL}$ filtrat hingga kering dalam cawan dangkal berdasar rata yang telah ditara, residu dipanaskan pada suhu $105^{\circ} \mathrm{C}$ hingga bobot tetap. Kadar Sari Larut Etanol dihitung dalam persen senyawa yang larut dalam etanol (95\%), terhadap ekstrak awal (Depkes RI, 2000).

Kadar sari laut etanol

$=\frac{\text { Berat Sari Etanol }(g)}{\text { Berat Ekstrak }(g)} \times\left(\frac{100}{20}\right) \times 100 \%$

4) Identifikasi Senyawa Metabolit Sekunder

a) Pembuatan Pereaksi

Pereaksi Mayer :

Sebanyak $1,36 \mathrm{~g} \mathrm{HgCl}_{2}$ dilarutkan dalam 60 $\mathrm{mL}$ aquades. Pada bagian yang lain larutkan $5 \mathrm{~g} \mathrm{KI}$ dalam $10 \mathrm{ml}$ aquades. Kedua larutan dicampur dan dicukupkan volumenya dengan aquades hingga 100 mL. (Mulyono, 2009)

Pereaksi Dragendroff :

Sebanyak $0,8 \mathrm{~g}$ bismuth (III) nitrat dilarutkan dalam $20 \mathrm{~mL}$ asam nitrat pekat. Pada wadah lain, sebanyak 27,2 g KI dilarutkan dalam $50 \mathrm{ml}$ aquades. Kemudian edua larutan dicampur dan didiamkan sampai memisah sempurna. Larutan yang jernih diambil dan dicukupkan volumenya dengan aquades hingga $100 \mathrm{~mL}$. (Mulyono, 2009)

Pereaksi Bouchardat :

Sebanyak 4 g KI dilarutkan sedikit demi sedikit ke dalam aquades, kemudian dilarutkan $2 \mathrm{~g}$ 
$\mathrm{I}_{2}$ sedikit demi sedikit ke dalamnya hingga larut dan volume dicukupkan dengan aquades hingga $100 \mathrm{~mL}$. (Mulyono, 2009)

b) Pengujian ekstrak :

Ekstrak ditimbang 1 gram, dilarutkan dalam etanol $70 \%$ sebanyak $10 \mathrm{ml}$, ditambahkan $25 \mathrm{~mL}$ air panas, suhu antara $60-80^{\circ} \mathrm{C}$ kemudian disaring. Filtrat digunakan untuk uji berikut :

(1) Uji senyawa Alkaloid

(a) Sebanyak 5 tetes filtrat dimasukkan ke dalam tabung reaksi, ditambahkan 2-3 tetes $\mathrm{HCl} 2 \mathrm{~N}$ dan 2 tetes pereaksi mayer. Bila terbentuk endapan putih atau kuning menunjukkan adanya senyawa alkaloid.

(b) Pereaksi Bouchardat

Sebanyak 5 tetes filtrat dimasukkan ke dalam tabung reaksi. Ditambahkan 2-3 tetes $\mathrm{HCl} 2 \mathrm{~N}$ dan 2 tetes pereaksi bouchardat. Bila terbentuk endapan coklat sampai hitam menunjukkan adanya senyawa alkaloid.

(c) Perekasi Dragendroff

Sebanyak 5 tetes filtrat dimasukkan ke dalam tabung reaksi. Ditambahkan 2-3 tetes dan 2 tetes pereaksi dragendorf. Bila terbentuk endapan jingga sampai merah coklat menunjukkan adanya senyawa alkaloid (Depkes RI, 1989).

(2) Uji Senyawa Flavonoid

Sebanyak 5 tetes filtrat ditambah sedikit serbuk magnesium, $1 \mathrm{~mL}$ asam klorida pekat dan 2 $\mathrm{mL}$ amil alkohol, dikocok dan dibiarkan memisah. Flavonoid positif jika terjadi warna merah, kuning, jingga pada lapisan amil alkohol.

(3) Uji Senyawa Tanin

Sebanyak 5 tetes filtrat diencerkan dengan air suling sampai tidak berwarna, ditambahkan 1-2 tetes pereaksi besi (III) klorida, jika terjadi warna biru atau hijau kehitaman menunjukkan adanya tanin (Atmoko dan Ma'aruf, 2009).

(4) Uji Senyawa Saponin

Sebanyak 5 tetes filtrat ditambahkan air secukupnya, dikocok kuat-kuat selama 10 detik. Jika terbentuk buih yang banyak selama tidak kurang dari 1 menit, setinggi $1 \mathrm{~cm}$ sampai $10 \mathrm{~cm}$ dan tidak hilang dengan penambahan 1 tetes asam klorida $2 \mathrm{~N}$ menunjukkan adanya senyawa saponin (Depkes RI, 1989).

(5) Uji Senyawa Steroid

Sebanyak 0,5 gram ekstrak dimaserasi dengan $10 \mathrm{ml} \mathrm{n}$-heksan selama 1 jam, lalu disaring. Filtrat diuapkan dalam cawan penguap dan sisanya ditambahkan 1-2 tetes asam sulfat pekat. Timbul warna hijau dan biru maka uji menunjukkan adanya steroid (Harborne, 1987).

b. Karakterisasi non spesifik

Karakterisasi non spesifik dalam penelitian ini meliputi :

1) Penetapan Kadar Air

Sebanyak 1 gram ekstrak, dikeringkan dalam oven selama 2 jam pada suhu $105^{\circ} \mathrm{C}$ dan ditimbang. Pengeringan dilanjutkan pada jarak 1 jam hingga perbedaan antara 2 penimbangan berturut-turut tidak lebih dari $0,25 \%$.

Kadar air $=\frac{b-(c-a)}{b} \times 100 \%$

a : berat cawan kosong $(\mathrm{g})$

$\mathrm{b}$ : berat simplisia awal $(\mathrm{g})$

$\mathrm{c}$ : berat cawan dan simplisia setelah di oven

(g) (Supomo et al., 2016).

\section{2) Penetapan Kadar Abu}

Sebanyak 2 gram ekstrak yang telah ditimbang seksama, dimasukkan ke dalam krus platina yang telah dipijarkan dan ditara, ratakan. Selama 3 jam dipijarkan dengan suhu $800^{\circ} \mathrm{C}$, kemudian didinginkan lalu ditimbangsampai bobot tetap. Jika cara ini arang tidak dapat dihilangkan, ditambahkan air panas, saring melalui kertas saring bebas abu. Pijarkan sisa dan kertas saring dalam krus yang sama. Filtrat dimasukkan ke dalam krus lalu diuapkan dan dipijarkan hingga bobot tetap, kemudian ditimbang. Kadar abu dihitung terhadap bahan yang telah dikeringkan di udara (Depkes RI, 2000).

Kadar abu total $=\frac{\text { Berat abu }(g)}{\text { Berat Ekstrak }(g)} \times 100 \%$

\section{3) Penetapan Kadar Abu Tidak Larut Asam}

Abu yang diperoleh dari penetapan kadar abu, dididihkan dengan $25 \mathrm{ml}$ asam klorida encer selama 5 menit, dikumpulkan bagian yang tidak larut dalam asam, disaring melalui krus kaca masir atau kertas saring bebas abu, dicuci dengan air panas, dipijarkan pada suhu $800^{\circ} \mathrm{C}$ dan ditimbang hingga bobot tetap. Kadar abu yang tidak larut dalam asam dihitung terhadap bahan yang dikeringkan di udara (Depkes RI, 2000). 
Kadar abu tidak larut asam

$$
=\frac{\text { Berat abu }(g)}{\text { Berat ekstrak }(g)} \times 100 \%
$$

\section{HASIL DAN PEMBAHASAN}

Dilakukan determinasi tumbuhan atau sampel terlebih dahulu, untuk memastikan bahwa sampel yang digunakan adalah benar Planchonia valida, familia Lecythidaceae. Selanjutnya dilakukan pengolahan simplisia, hingga diperoleh simplisia serbuk pucuk daun putat dengan derajat halus tertentu.

Ekstraksi serbuk simplisia pucuk daun putat menggunakan metode maserasi.

Metode maserasi merupakan cara penyarian sederhana dimana pelarut akan menembus dinding sel dan masuk ke dalam rongga sel yang mengandung zat aktif. Keuntungan dari metode maserasi adalah cara pengerjaaanya sederhana, mudah, alat yang digunakan sederhana, dan faktor kerusakan zat aktif lebih kecil karena dalam metode maserasi tidak menggunakan panas yang mungkin dapat merusak zat aktif yang disari. Kerugian dari metode maserasi adalah pengerjaanya lama dan penyariannya kurang sempurna. Penggunaan pelarut etanol, karena etanol 70\% dapat melarutkan senyawa fitokimia lebih maksimal. Etanol 70\% masih mengandung air yang cukup banyak (30\%) yang membantu proses ekstraksi sehingga sebagian senyawa tersebut ada yang dapat tersari dalam etanol dan ada pula yang tertarik dalam air (Melodita, 2011). Remaserasi dilakukan sebanyak 2 kali. Pengadukan pada proses maserasi dilakukan dengan pengaduk kinetik yang bertujuan untuk meningkatkan kontak antar serbuk simplisia dengan pelarut sehingga zat-zat aktif dalam serbuk simplisia banyak yang tersari dalam larutan penyari. Pengadukan dilakukan selama 3 jam kemudian didiamkan selama 21 jam untuk memberikan kesempatan zat aktif yang tersari di dalam sel berdifusi keluar sel (Salamah dan Erlinda, 2015). Maserat yang diperoleh diuapkan hingga diperoleh ekstrak kental. Berat ekstrak kental yang diperoleh sebanyak 28,32 gram, sehingga rendemen yang diperoleh $14,16 \%$.

Hasil karakterisasi spesifik ekstrak etanol meliputi pemeriksaan organoleptik, kadar sari larut air dan kadar sari larut etanol, dan senyawa metabolit sekunder adalah sebagai berikut:

\section{Uji Organoleptik Ekstrak Etanol Daun Putat}

Penentuan parameter organoleptik ekstrak ini bertujuan untuk memberikan pengenalan awal ekstrak secara objektif dan sederhana yang dilakukan dengan panca indra.

Tabel 1. Hasil uji organoleptik

\begin{tabular}{cll}
\hline No. & \multicolumn{1}{c}{ Parameter } & \multicolumn{1}{c}{ Hasil } \\
\hline 1 & Konsistensi & Kental \\
2 & Warna & Coklat kehitaman \\
3 & Bau & Khas \\
4 & Rasa & Pahit sepat \\
\hline
\end{tabular}

\section{Skrining Fitokimia}

Skrining fitokimia terhadap ekstrak dilakukan untuk mendapatkan informasi golongan senyawa metabolit sekunder yang terdapat dalam ekstrak etanol daun putat.

Tabel 2. Hasil skrining fitokimia

\begin{tabular}{clc}
\hline No. & Golongan senyawa & Hasil \\
\hline 1 & Alkaloid & $(+)$ \\
2 & Flavonoid & $(+)$ \\
3 & Tanin & $(+)$ \\
4 & Saponin & $(+)$ \\
5 & Steroid & $(+)$ \\
\hline
\end{tabular}

Keterangan : $+=$ mengandung senyawa kimia

Uji alkaloid dilakukan dengan menambahkan $\mathrm{HCl} 2 \mathrm{~N}$ ke dalam sampel kemudian ditetesi dengan pereaksi mayer memberikan endapan warna kuning, dengan pereaksi bouchardat memberikan warna merah dan dengan perekasi dragendrof menunjukkan adanya endapan coklat. Sehingga ekstrak etanol daun putat positif mengandung alkaloid. Senyawa alkaloid berkhasiat sebagai anti diare, anti diabetes, anti mikroba dan anti malaria (Ningrum et al., 2016).

Uji flavonoid menunjukkan warna jingga yang berarti ekstrak etanol daun putat, positif mengandung senyawa flavonoid. Penambahan logam $\mathrm{Mg}$ dan $\mathrm{HCl}$ pekat dalam uji ini berfungsi untuk mereduksi inti benzopiron yang terdapat dalam struktur flavonoid sehingga terbentuk perubahan warna menjadi merah tua atau jingga (Setyowati et al.,2014). Flavonoid memiliki berbagai efek bioaktivitas termasuk anti virus, anti inflamasi (Qinghu et al., 2016), anti penuaan, dan antioksidan (Vanessa et al.,2014).

Uji senyawa tanin memberikan hasil positif yaitu terbentuknya warna hijau kehitaman setelah 
penambahan pereaksi $\mathrm{FeCl}_{3} 1 \%$. Menurut Kusumaningsih et al. (2015), penambahan $\mathrm{FeCl}_{3} 1 \%$ menghasilkan suatu warna hijau kehitaman karena reaksi antara tanin dengan $\mathrm{FeCl}_{3}$ membentuk senyawa kompleks. Tanin memiliki khasiat sebagai astringen, antidiare, antibakteri dan antioksidan (Malangngi et al., 2012)

Uji senyawa saponin memberikan hasil positif yaitu terbentuknya busa permanen setelah dikocok dan dengan penambahan $\mathrm{HCl} 2 \mathrm{~N}$ busa tidak hilang. Wardana dan Tukiran (2016), menyatakan bahwa prinsip uji saponin adalah reaksi hidrolisis senyawa saponin menjadi aglikon dan glikonnya yang ditandai dengan terbentuknya busa yang stabil. Hal ini dikarenakan senyawa yang memiliki gugus polar dan non polar bersifat aktif permukaan sehingga saat dikocok dengan air, saponin dapat membentuk busa. Penambahan $\mathrm{HCl} 2 \mathrm{~N}$ mengakibatkan kestabilan busa semakin lama. Penambahan $\mathrm{HCl} 2 \mathrm{~N}$ bertujuan untuk menambah kepolaran sehingga gugus hidrofil akan berikatan lebih stabil dan buih yang terbentuk menjadi stabil (Simaremare, 2014). Saponin berkhasiat sebagai anti oksidan, anti inflamasi, anti bakteri, dan anti jamur sehingga bisa digunakan untuk proses penyembuhan luka (Novitasari dan Dinda, 2016).

Uji senyawa steroid memberikan hasil positif, yaitu dengan terbentuknya warna hijau kebiruan. Menurut Sangiet al. (2013) kandungan terpenoid atau steroid dalam tumbuhan yang diuji dengan menggunakan pereaksi Liebermann-Burchard (asam asetat anhidrat dan asam sulfat pekat) yang nantinya akan memberikan warna merah jingga atau ungu untuk terpenoid dan hijau kebiruan untuk steroid. Steroid diketahui berperan penting bagi tubuh dalam menjaga keseimbangan garam, mengendalikan metabolisme dan meningkatkan fungsi organ seksual serta perbedaan fungsi biologis lainnya (Nasrudin et al.,2017)

Kadar Sari Larut Air dan Kadar Sari Larut Etanol Ekstrak Etanol Daun Putat

Tabel 3. Hasil penetapan kadar

\begin{tabular}{clc}
\hline No. & \multicolumn{1}{c}{ Parameter } & $\begin{array}{c}\text { Kadar Rata-rata } \\
(\%)\end{array}$ \\
\hline 1 & Kadar sari larut air & 62,50 \\
2 & Kadar sari larut etanol & 48,75 \\
\hline
\end{tabular}

Penetapan kadar sari larut dalam air bertujuan untuk memberikan gambaran awal jumlah kandungan senyawa kimia bersifat polar yang dapat diekstraksi, hasil rata-rata yang diperoleh dalam ekstrak daun putat sebesar 62,50\%. Penetapan kadar sari larut etanol bertujuan untuk mengetahui kadar senyawa yang larut dalam etanol, hasil rata-rata yang diperoleh sebesar $48,75 \%$. Jumlah senyawa ekstrak daun putat yang terlarut dalam etanol lebih kecil dari pada jumlah senyawa yang terlarut dalam air. Hal ini disebabkan air dapat melarutkan senyawa polar yaitu flavonoid, saponin, dan tanin. Hasil karakterisasi non spesifik ekstrak etanol daun putat meliputi kadar air, kadar abu total dan kadar abu tidak larut asam.

\section{Kadar Air Ekstrak}

Penetapan kadar air ekstrak bertujuan untuk memberikan rentang tentang besarnya kandungan air yang terdapat dalam ekstrak. Ekstrak yang diperoleh merupakan ekstrak kental. Hasil rata-rata penetapan kadar air dalam ekstrak daun putat sebesar 23,00\%. Menurut Voight (1995), suatu ekstrak dinyatakan sebagai ekstrak kental jika memiliki kadar air 5$30 \%$,

Menurut Supriningrum et al. (2017) kadar air yang besar dapat menyebabkan pertumbuhan mikroba karena air merupakan media pertumbuhan mikroorganisme dan juga sebagai media terjadinya reaksi enzimatis yang dapat menguraikan senyawa aktifnya.

\section{Kadar Abu Total}

Penetapan kadar abu total bertujuan memberikan gambaran kandungan mineral internal dan eksternal yang berasal dari proses awal sampai terbentuknya ekstrak (Depkes, 2000). Rata-rata kadar abu total yang diperoleh adalah $6,47 \%$. Menurut Saragih (2014) semakin tinggi kadar abu semakin tinggi mineral yang dikandung dalam bahan tersebut. Mineral tersebut dapat berupa garam organik (misalnya garam dari asam malat, oksalat, pektat), garam anorganik (misalnya fosfat, karbonat, klorida, sulfat nitrat dan logam alkali), atau berupa mineral yang terbentuk menjadi senyawa kompleks bersifat organik (Kartikasari et al., 2014). 


\section{Kadar Abu Tidak Larut Asam}

Metode penetapan kadar abu tidak larut asam menggunakan abu yang diperoleh dari penetapan kadar abu total denganpenambahan $\mathrm{HCl}$ bertujuan untuk mengetahui kontaminasi yang bersumber dari faktor eksternal seperti pasir dari tanah dan debu yang melekat pada waktu pengeringan (Suharti et al., 2017). Rata-rata kadar abu tidak larut asam sebesar 0,06\%. Menurut Kartikasari et al. (2014) adanya kandungan abu tidak larut dalam asam yang rendah menunjukkan adanya pasir atau pengotor yang lain dalam kadar yang rendah.

\section{KESIMPULAN}

Karakteristik spesifik ekstrak etanol daun putat secara organoleptik berupa ekstrak kental, berwarna coklat kehitaman, berasa pahit sepat dan berbau khas. Kadar rata-rata sari larut air sebesar $62,50 \%$ dan kadar rata-rata sari larut etanol sebesar $48,75 \%$. Ekstrak etanol daun putat mengandung senyawa kimia alkaloid, flavonoid, tanin,saponin, dan steroid. Karakteristik non spesifik ekstrak etanol daun putat meliputi kadar air rata-rata sebesar $23,00 \%$, kadar abu rata-rata $6,47 \%$ dan kadar abu tidak larut asam rata-rata $0,06 \%$.

\section{DAFTAR PUSTAKA}

Atmoko, T., dan Ma'aruf, A. 2009. Uji Toksisitas Dan Skrining Fitokimia Ekstrak Tumbuhan Sumber Pakan Orang Utan Terhadap Larva Artemia salina Leach. Jurnal penelitian Hutan dan Konservasi Alam VI (1): 39

Departemen Kesehatan RI. 1989.Materia Medika Indonesia. Edisi V Jakarta: Depkes RI. Hal: 249 dan 252

Departemen Kesehatan RI. 2000. Parameter Standar Umum Ekstrak Tumbuhan Obat. Jakarta: Depkes RI. Hal: 3, 9-10, 13, 14, dan 17.

Departemen Kesehatan RI. 2008. Farmakope Herbal Indonesia. Jakarta: Depkes RI. Hal: 174.

Harborne, J.B. 1987. Fitokimia Penuntun Cara Modern Menganalis Tumbuhan. Diterjemahkan oleh Kosasih Padmawinata \& Iwang Soedirjo, Penerbit ITB: Bandung. Hal: 64.
Hardiyanto, E.B. 2008. Seed Collection and Handling Putat (Planchonia valida (Blume)). Jakarta: Directorate General of Land Rehabilitation and Social Forestry. Hal: 1.

Hidayat, D., dan Hardiyansyah, G. 2012. Studi Keanekaragaman Jenis Tumbuhan Obat di Kawasan IUPHHK PT. Sari Bumi Kusuma Camp Tontang Kabupaten Sintang. PJ Vokasi. 8(2): 61-68.

Kartikasari, D., Nurkhasanah, Suwijiyo, P. 2014. Karakterisasi Simplisia Dan Ekstrak Etanol Daun Bertoni (Stevia rebaudiana) Dari Tiga Tempat Tumbuh.

Proceeding Seminar Nasional Perkembangan Terbaru Pemanfaatan Herbal Sebagian Agen Preventif Pada Terapi Kanker.. Halaman:149150.

Kusumaningsih, T., Nur J.A., Suci, W., Dewi, R.T.W., dan Khoirul, F. 2015. Pengurangan Kadar Tanin Pada Ekstrak Stevia rebaudiana dengan menggunakan Karbon Aktif. Jurnal penelitian kimia. 11(1). Hal: 85

Malangngi, L.P., Meiske, S.S, dan Jessy J.E.P. 2012. Penentuan kandungan tanin dan uji aktivitas antioksidan ekstrak biji buah alpukat (Persea americana Mill). Jurnal Mipa Unsrat Online 1. Manado: Jurusan Kimia FMIPA Unsrat, 2012. Hal: 5

Melodita, R. 2011. Identifikasi pendahuluan senyawa fitokimia dan uji aktivitas antioksidan ekstrak daun cincau hitam (Mesona palustris bl.) dengan perlakuan jenis pelarut. Skripsi. Malang: Universitas Brawijaya.

Mulyono, 2009 . Membuat Reagen Kimia Di Laboratorium. Jakarta : Bumi Aksara. Hal : 260-273

Nasrudin, Wahyono, Mustofa, dan Ratna, A.S. 2107. Isolasi senyawa steroid dari kulit akar senggugu (Clerodendrum serratum L.Moon). Jurnal Ilmiah Farmasi UNSRAT 6(3). Hal: 333

Ningrum, R., Elly, P., dan Sukarsono. 2016. Identifikasi Senyawa Alkaloid Dari Batang Karamunting (Rhodomyrtus tomentosa) Sebagai Bahan Ajar Biologi Untuk SMA kelas X. Jurnal Pendidikan Biologi Indonesia 2(3): hal 231 
Novitasari, A.E., dan Dinda, Z.P. 2016. Isolasi dan Identifikasi Saponin Pada Ekstrak Daun Mahkota Dewa Dengan Ekstraksi Maserasi. Jurnal Sains 6(12). hal: 11.

Qinghu, W., Jinmei, J., Nayintai, D., Narenchaoketu, H., Jingjing, H., dan Baiyinmuqier, B. 2016. AntiInflammatory effects, nuclear magnetic resonance identification and highperformance liquid chromatography isolation of the total flavonoids from Artemisia frigida. Journal of Food And Drug Analysis, 24: 385-391.

Salamah, N., dan Erlinda W. 2015. Aktivitas Antioksidan Ekstrak Metanol Daun Kelengkeng ( Euphoria longan ( L ) Steud .) Dengan Metode Penangkapan Radikal 2,2'difenil-1-pikrilhidrazil. Pharmaciana,5(1) Jurnal Kefarmasian, Universitas Ahmad Dahlan.

Sangi, M.S., Lidya, I.M., dan Maureen, K. 2013. Uji Toksisitas Dan Skrining Fitokimia Tepung Gabah Pelepah Aren (Arenga pinnata). Jurnal Ilmiah Sains 12(2). Hal: 132

Saragih, R. 2014. Uji kesukaan panelis pada teh daun torbangun (Coleus ambonicus). EJournal WIDYA Kesehatan dan Lingkungan, $1(1): 52$

Setyowati, W.A.E., Ariani, S.R.D., Ashadi, Mulyani, B., dan Rahmawati, C.P. 2014. Skrining fitokimia dan identifikasi komponen utama ekstrak metanol kulit durian (Durio zibenthinus murr.) varietas Petruk.,Seminar Nasional Kimia dan Pendidikan Kimia VI. Prodi Pendidikan Kimia Jurusan FMIPA FKIP Universitas Surakarta. Hal: 275

Simaremare, E.S. 2014. Formulasi dan evaluasi daun gatal (Laportea decumana (Roxb.) Wedd) sebagai kandidat antinyeri tanaman obat Indonesia. Pharmacy, 11(1): 105

Suharti, N., dan Yossi, G.L., dan Elidahanum, H. 2017. Karakterisasi simplisia dan ekstrak etanol serta uji aktivitas antioksidan rimpang jahe merah (Zingiber Officinale Var. Vubrum Theilade) yang diinokulasi fungi mikoriza arbuskula (FMA). Jurnal Sains dan Teknologi Farmasi 19(1); 70

Supriningrum, R. Fitri H., dan Liya. 2017. Karakterisasi dan skrining fitokimia daun singkil (Premna corymbosa Rottl \& Wild). Jurnal Ilmiah Ibnu Sina, 2(2): 241

Supomo., Supriningrum, R., dan Risaldi, J. 2016. Karakterisasi dan skrining fitokimia daun kerehau (Callicarpa longifolia Lamk). Jurnal Kimia Mulawarman, 13 (2) .

Vanessa, M., Munhoza, R.L., José R.P., João, A.C., Zequic, E., Leite, M., Gisely, C., Lopesa, J.P., dan Melloa. 2014. Extraction of flavonoids from tagetes patula: process optimization and screening for biological activity”. Rev Bras Farmacogn, 24 (5). : 576-583.

Voight. 1995. Buku Pelajaran Teknologi Farmasi. Yogyakarta: Gadjah Mada University Press. Hal 577.

Wardana, A.P., dan Tukiran. 2016. Skrining fitokimia dan aktivitas antioksidan ekstrak kloroform tumbuhan gowok (Syzygium polycephalum). Prosiding Semnas Kimia dan Pembelajarannya, Jurusan Kimia FMIPA Universitas Negeri Surabaya. Hal: 4 